\title{
Forgiveness Therapy as A Religious Conflict Resolution of Violence Conflict (Carok) in Pamekasan Madura
}

\author{
Mohammad Takdir \\ Institut Ilmu Keislaman Annuqayah (INSTIKA), Sumenep, Indonesia \\ email: mohammadtakdir86@gmail.com \\ M. Mushthafa \\ Institut Ilmu Keislaman Annuqayah (INSTIKA), Sumenep, Indonesia \\ email: musthov@gmail.com \\ Wahyudi Akmaliah \\ Department of Malay Studies, National University of Singapore, Singapore \\ email:wahyudi@u.nus.edu
}

\begin{abstract}
This research efforts to answer the problem of conflict resolution models were used by Madurese society to resolve carok and why forgiveness can overcome carok conflict. The research tries to understand how the forgiveness stages between the parties involved in the case of carok in Madura? This research used a qualitative method to explore the power of forgiveness in the resolve of carok in Bujur Tengah Village, Batu Marmar, Pamekasan. In collecting data, the researcher used observation, interview, documentation, and triangulation techniques, while the analysis techniques used were data reduction, data presentation, and conclusion drawing. This research shows that the forgiveness model becomes a conflict resolution capable of controlling anger and retaliation to achieve true reconciliation. That is because the forgiveness mechanism has extraordinary power to rebuild the relationship or restore the effects of trauma from the
\end{abstract}

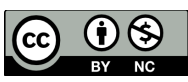

DOI: $10.19105 /$ karsa.v29i1.4419 
victim's family. The forgiveness mechanism of forgiveness in the case of carok cannot be separated from the role of Kiai to resolve the disputes of land swap overland (village treasury) between two parties. The Kiai carries out many stages to accelerate the achievement of reconciliation; namely restoring security conditions, embracing the families of carok victims, strengthening friendship to prevent counterconflict, the tabayyun process by presenting conflicting parties, accelerating dialogue, and holding reconciliation studies.

[Penelitian ini berusaha menjawab persoalan tentang model resolusi konflik yang digunakan masyarakat Madura dalam mengatasi kasus carok dan mengapa pemafaan mampu mengatasi konflik carok. Penelitian ini juga untuk memahami bagaimana tahapan-tahapan pemafaan secara total diantara pihak-pihak yang berkonflik dalam kasus carok di Madura? Penelitian ini menggunakan metode kualitatif untuk mengeksplorasi kekuatan pemaafaan dalam kasus carok di desa Bujur Tengah, Batu Marmar, Pamekasan. Dalam proses pengumpulan, peneliti menggunakan teknik observasi, wawancara, dokumentasi, dan tringulasi, sementara teknik analisa yang digunakan adalah dengan reduksi data, penyajian data, dan penarikan kesimpulan. Penelitian ini menunjukkan bahwa model pengampunan menjadi penyelesaian konflik dalam mengendalikan kemarahan dan pembalasan untuk mencapai rekonsiliasi sejati dalam kasus carok. Hal ini dikarenakan, mekanisme pengampunan memiliki kekuatan luar biasa untuk membangun kembali hubungan atau mengembalikan efek trauma dari keluarga korban. Model pemaafan dalam kasus carok ini tidak bisa lepas dari peran figur kiai untuk menyelesaikan sengkata tukar guling tanah percaton (kas desa). Ada banyak tahapan yang dijalankan para kiai untuk mempercepat tercapainya rekonsiliasi, yaitu pemulihan kondisi keamanan, merangkul keluarga korban carok, memperkuat silaturrahmi sebagai proses pencegahan konflik balasan, proses tabayyun dengan menghadirkan pihak yang berkonflik, mempercepat dialog (musyawarah), dan mengadakan pengajian rekonsiliasi sebagai langkah antisipatif dan responsif.]

Keywords: carok; conflict resolution; forgiveness; reconciliation; Madura

\section{Introduction}

One of the violence that is deeply rooted in the life of the Madurese community is the carok culture, which has become a symbol

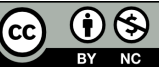

DOI: 10.19105/karsa.v29i1.4419 
of identity for the defense of self-respect and family dignity. The carok culture is mentioned by some researchers to be the most effective conflict resolution for defending self-esteem against humiliation and abuse that carries the family name. This manner of conflict resolution can be referred to as self-punishment, which is a manifestation of the attitude of the Madurese society. Carok is a social phenomenon, but not every conflict or violence must be associated with carok. ${ }^{1}$ The carok behavior that often occurs in Madura, makes this action a culture that gets social recognition to represent self-respect and self-dignity. Carok is violent behavior related to property, the throne, and women. The ethnographic expression, which states, "ango'an pote tolang, etembang pote mata" (it is better to die than to be ashamed), is one of the triggers of the birth of $\operatorname{carok}^{2}$ and becomes the center of a conflict that is deeply rooted in the life of the Madurese society. ${ }^{3}$

The carok phenomenon in Madura is one of the most unique as an expression of conflict resolution involving each individual or community group. Carok in Madura is considered unique because it is an expression of violence that is recognized socio-culture and even obtains justification from the community. In the case of carok, the Madurese community adheres to a stereotype that displays a negative image as an ethnic group that likes to fight or act violently. Madurese community has agreed on carok as a norm that should be implemented in a disturbance or harassment of family dignity. Carok has the meaning of persecution which has a special reason, and wherein sociological studies can be interpreted as a pattern of behavior that functions as a model. Carok is a sharp armed fight (sickle) between one person and

\footnotetext{
1 A. Dharmawan, G.G. Aji and Mutiah, "Madurese Cultural Communication Approach," Journal of Physics: Conference Series 953, no. 1 (2018): 2. http://doi.org/ 10.1088/1742-6596/953/1/012195.

2 Nur Wahyu Rochmadi, "Virtues of the Madura Society," Advances in Social Science, Education, and Humanities Research 524 (2020): 161-166. https://doi.org/10.2991/ assehr.k.210204.025

3 Mien Ahmad Rifai, Manusia Madura: Perilaku, Etos Kerja, Penampilan, dan Pandangan Hidupnya (Yogyakarta: Pilar Media, 2007), 143.
}

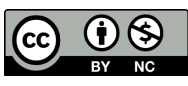

DOI: $10.19105 /$ karsa.v29i1.4419 
another, which begins with an agreement regarding time and place. ${ }^{4}$ However, the meaning of carok has now undergone a fairly unequal shift about conflicts between individuals that have turned into collective (group) conflicts. ${ }^{5}$

This research took on of the carok in Bujur Tengah village, Batu Marmar District, Pamekasan Madura, which occurred in July 2006. This carok case drew a lot of public attention because many victims had lost their lives as a result of the incident. In this carok, the murder was carried out spontaneously or sporadically, without preparation, carried out collectively, without ritual, and resulted in female victims. The Madurese considers Carok to be solely men's business, not women's. This is consistent with the familiar expression among the Madurese community that oreng lake mate acarok, oreng bine' mate arembi (men die from carok, women die from childbirth). ${ }^{6}$

We are the authors, in this case, should change the violance's paradigm into a first step to build harmony and uphold human values as a fundamental principle in spreading the importance of forgiveness to everyone involved in carok. Moreover, the Madurese society has deeply rooted values of harmony, such as the expression "rampak naong bringen korong" (a calm, peaceful atmosphere like being under a shady banyan tree). ${ }^{7}$ The case of carok is very important to be criticized to restore the correct meaning. The definition of past carok does not mean second revenge or involving other people in the case of carok, because every action that disturbs the dignity of others must be resolved personally. When referring to the meanings of past carok, the forgiveness approach can be an alternative in resolving carok. Forgiveness is a concrete step to turn anger into patience, to feel the

\footnotetext{
4 Abdurrahman, Masalah Carok di Madura. Buku Madura III (Surabaya: Sinar Terang, 1987), 48.

${ }^{5}$ Peg Pickering, How to Manage Conflict: Kiat Menangani Konflik, trans. Masri Maris (Jakarta: Erlangga, 2001), 12.

6 A. Latief Wiyata, Carok: Konflik Kekerasan dan Harga Diri Orang Madura (Yogyakarta: LKiS, 2002), 185.

${ }^{7}$ Moh. Fatah Yasin and Fimeir Liadi, Representasi Nilai Budaya Madura \& Dayak dalam Sastra (Yogyakarta: IRCiSoD, 2007), 93.
}

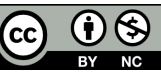

DOI: 10.19105/karsa.v29i1.4419 
beautiful harmony of love, the absence of enmity, and mutual respect for other people. ${ }^{8}$

In the context of the diversity of the Madurese, carok is indeed immoral attitude that harms many parties and is against the law. Even though people outside Madura already perceive carok as a negative tradition and an act against state law, but at least a paradigm shift towards carok can be diverted to seek the best solution for any conflicts. This paradigm shift of carok culture was intended to reduce the public's perception that carok is not just an act of ordinary murder, but a mechanism with meaning. That is where a new paradigm is needed that can strengthen brotherhood and kinship ties by involving all elements of Madurese society, especially Kiai figures who are the main role models. ${ }^{9}$

The new approach to reducing carok and building a peaceful culture is a strategic vehicle for creating a life without violence, compassion, tolerance, and love harmony. The conflict resolution model implemented in the case of carok is a forgiveness approach that reflects humility in religion and a sincere spirit to forgive one another which is filled with the values of harmony and love manifested. In every religious teaching, it has been taught that conflict can be controlled by the willingness of everyone to take a path of forgiveness. The Forgiveness approach can inspire everyone to live calmly without hatred and hostility. ${ }^{10}$

There are some reasons behind the forgiveness approach to reduce carok in Bujur Tengah village, Batu Marmar, Pamekasan Madura. First, there is a tendency for the increasing culture of violence (carok) which can threaten the breaking of friendship and kinship ties and destroy the order in the life of the Madurese. Second, carok culture and other forms of violence are very contrary to the mission of any religious teachings that oppose acts of violence in the name and motive

\footnotetext{
${ }^{8}$ Maulana Wahiduddin Khan, The Ideology of Peace (New Delhi: Goodword Books, 2010), 12.

${ }^{9}$ Fatah Yasin and Fimier Liadi, Representasi Nilai Budaya Madura, 99.

${ }^{10} \mathrm{M}$. Abu Fitriana, The Spirit of Forgiveness: Hidup Indah Dengan Memaafkan (Solo: Tinta Medina, 2013), 96.
}

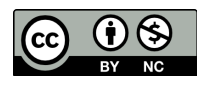

DOI: 10.19105/karsa.v29i1.4419 
of any kind, including the motives of self-respect and dignity. Third, the tendency of carok to be carried out from generation to generation is getting stronger because it keeps an act of revenge that cannot be suppressed. This intergenerational enmity can lead to even greater acts of violence, so there is a need for humility to end conflicts through forgiveness as psychological therapy.

The forgiveness approach can be present in the carok conflict through the role of the Kiais, who has become a socio-religious figure in the Madurese society. The Kiai uses a religious-cultural approach to provide an understanding of the important spirit of brotherhood and kinship through a spiritual way that can touch their consciences and souls. Based on the role of the Kiais, the forgiveness could be accepted as approach and media in restoring a relationship that broken as initial step towards of genuine reconciliation.

Research on the carok that occurred in Madura has been carried out by scholars interested in the uniqueness of the carok as a symbol of Madurese identity. Latief Wiyata research is an anthropological study that aims to understand carok as culture-based violence. ${ }^{11}$ Some outside researchers, such as Hube de Jonge (1995), ${ }^{12}$ Glen Smith (1997), ${ }^{13}$ and E. Touwen-Bouwsma (1989) ${ }^{14}$ are Western scholars who are quite familiar among the Madurese community, because various studies have been conducted to explore the uniqueness of Madura as the third largest ethnic group in this archipelago. The three researchers attempted to reveal the carok tradition inherent in the life of the Madurese people.

Another that, some research from Indonesia was relevant to the carok culture as a part of Madurese society. Carok is the

\footnotetext{
${ }^{11}$ A. Latief Wiyata, Carok, 185.

${ }^{12}$ Hube de Jonge, "Stereotypes of Madures," In H. D. K. Van Diik, Across Madura Strait: The Dynamic of an Insular Society (Leiden: KITLV Press, 1995), 232.

13 Glen Smith, "Carok Violence in Madura, From Historical Conditions to Contemporary Manifestations," Folk: Journal of the Danish Ethnographic Society, no. 39 (1997): 58, https://koha.ups2259.vjf.cnrs.fr/cgi-bin/koha/opac-detail.pl?biblio number $=12297$.

14 Elly Touwen-Bouwsma, "Kekerasan di Madura," In Huub De Jonge, Agama, Kebudayaan, dan Ekonomi: Studi-Studi Interdisipliner tentang Masyarakat Madura (Jakarta: Rajawali Press, 1989), 128.
}

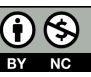

DOI: 10.19105/karsa.v29i1.4419 
institutionalization of violence that historically has been practiced by several Madurese since several centuries ago. Carok also starts with the weakness of state authority to control the source of violence and the inability to provide justice to the community. Carok is an act of violence that has been passed down from generation to generation. ${ }^{15}$ The motives of carok were to defend the dignity of the self and group, maintain the pragmatic interests based on egocentric, and preserve life feasibility with economic and political perspectives. ${ }^{16}$ Carok tradition is understood as a peculiarity of customs and legal violations that are justified by Madurese society. ${ }^{17}$ The case of carok may be caused by a different reason, namely, women, ${ }^{18}$ stealing accusations, legacy disputes, and revenge. ${ }^{19}$

In the case of carok, the dynamics of the culture of violence in Madurese society both have the main actors, namely blater and kiai. Blater has the power to control violence which often a hegemony in Madurese society. For Madurese, the blater has several other names, for example, bajingan (strongman) in Pamekasan and Sumenep. ${ }^{20}$ Likewise, the Kiai, with their capacity and ability to interpret religious discourse, can hegemony the deepest structures in the inner space,

${ }^{15}$ Syaiful Rohman, Margaretha Hanita, and Ahmad Luthfi, "The Influence of Carok Culture on Reproductive Violence for the Younger," ICSGS (Jakarta: Universitas Indonesia, 2018), 5, https://doi.org/10.4108/eai.24-10-2018.2289677

${ }^{16}$ Purwati Ayu Rahmi, Cahyaningrum Dinis, Putri Kholifatul Wanda, and Listiyawaty Yuyun, "Meaning of Carok For Maduranese (Indonesian Tribe): A Case Study in Sampang," RJOAS 2, no. 74 (2018):12-14, https://doi.org/10.18551/rjoas.2018-02.02.

${ }^{17}$ Purwati Ayu Rahmi, "Maduranese Meaning About Carok Case Study in Sampang Regency, Madura Island," ASEAN Academic Society International Conference (Thailand: Indonesian Student Association in Thailand (PERMITHA) (2018): 291292.

18 Syamsu Budiyanti, Hotman M. Siahaan, and Kris Nugroho, "Social Communication Relation of Madurese People in Max Weber Rationality Perspective," Jurnal Studi Komunikasi 4, no. 2 (2020): 389-409, https://doi.org/10.25139/jsk.v4i2.2447.

${ }^{19}$ Haris, "Religiosity of Violence through Pesantren: A Method to Prevent Carok in Madura Tribe of Indonesia," Journal of Law, Policy, and Globalization 2, no. 57 (2017): 55-56, https://www.iiste.org/Journals/index.php/JLPG/article/view/35172.

${ }^{20}$ Dinara Maya Julijanti, Yayan Sakti Suryandaru, and Myrtati Dyah Artaria, "Remo Celebration in Blater Community: Traditional Ritual Communication in Madura," Jurnal Studi Komunikasi 4, no. 2 (2020): 298, https://doi.org/10.25139/jsk.v4i2.2445.

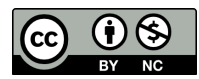

DOI: $10.19105 /$ karsa.v29i1.4419 
thoughts, and behavior of society. ${ }^{21}$ This carok behavior requires proper conflict resolution to reduce the escalation of violence among the Madurese community. Research on the forgiveness approach for conflict resolution and peace was conducted by researchers. The research emphasizes the importance of forgiveness as a particle forming peace and justice in the crisis happening to the world today, including Indonesia. In interpersonal relationships, forgiveness is one of the therapies to restore traumatic conditions caused by violence and conflict. ${ }^{22}$

The research on forgiveness and reconciliation as conflict resolution is very important for all societies. Forgiveness is not understood as an attempt to "forget", but it is a process of encounter, healing, uncovering true new choices, and self-improvement for the future. ${ }^{23}$ Besides, Desmond Tutu said that forgiveness in cases of violence is important, because "there is no future without forgiveness." 24 The forgiveness approach as a model for conflict resolution was carried out by Marc Gopin about the importance of genuine forgiveness. ${ }^{25}$ For this reason, Lewis Smedes reveals another way to avoid hurt feelings, besides forgiving is forgetting. ${ }^{26}$ Forgiveness is a step toward true reconciliation. $^{27}$

${ }^{21}$ Abdur Rozaki, Menabur Kharisma, Menuai Kuasa: Kiprah Kiai dan Blater sebagai Rezim Kembar di Madura (Yogyakarta: Pustaka Marwa, 2004), 3.

${ }^{22}$ Yoachim Agus Tridatno, B. Banawiratma, dan Wening Udasmoro, "Forgiveness: Its Power and Complexities," Orientasi Baru 20, no. 2 (2011): 12, https://ejournal.usd.ac.id/index.php/job/article/view/1268.

23 Geiko Muller Fahrenholz, The Art of Forgiveness: Theological Reflections on Healing and Reconciliation (Jeneva: WCC Publication, 1997), 78.

${ }^{24}$ Desmond Tutu, No Future Without Forgiveness (London: Rider, 1999), 123.

${ }^{25}$ Marc Gopin, "Forgiveness as an Element of Conflict Resolution in Religious Cultures: Walking the Tightrope of Reconciliation and Justice," in Mohammed AbuNimer (ed.), Reconciliation, Justice and Coexistence: Theory and Practice (Lanham, MD: Lexington Books, 2001), 23.

${ }^{26}$ Lewis B. Smedes, Forgive and Forget: Healing the Hurts We Don't Deserve (San Francisco: Harpers, 1984).

27 Yehudit Auerbach, "Forgiveness and Reconciliation: The Religious Dimension," Terrorism and Political Violence 17, no. 1 (2005): 469-485, https://doi.org/10.1080/ 09546550590929174.

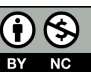

DOI: $10.19105 /$ karsa.v29i1.4419 
Based on some of the studies above, there is no one study related to the relationship of forgiveness with the case of carok in Madura. This study effort to describe the stages of forgiveness as a model for conflict resolution in the case of carok among the Madurese. As proof, this forgiveness mechanism has become part of the resolution of the carok conflict that occurred in Pamekasan Madura. This is because the forgiveness mechanism is a therapy that can reduce and negate the smell of anger, enmity, and revenge in every human soul so that it becomes the first step towards genuine peace and reconciliation. ${ }^{28}$

\section{Methods}

This research is used qualitative research that seeks to describe events, people's behavior, or a situation at a certain place in the form of a narrative. This type of research is descriptive-analytical which aims to describe the symptoms or facts about an event that occurred. ${ }^{29}$ Descriptive research is conducted to explore the behavior of a group of people, an object, a condition, a system of thought, or a class of events in the present. ${ }^{30}$

This research focuses on the case of Carok in Bujur Tengah, Batu Marmar, Pamekasan in 2006. In the field data collection stage, this study used several important instruments. First, the observation technique is a method for observing Carok events, namely as a participant as an observer. ${ }^{31}$ Second, the interview technique is used to extract data from informants more deeply (in-depth interview), ${ }^{32}$ namely the Kiai, blater, and society leaders. Third, the triangulation method is used to check the correctness of the data, both the source and the

\footnotetext{
${ }^{28}$ Asep Haerul Gani, Forgiveness Therapy: Maafkanlah, Niscaya Dadamu Lapang (Yogyakarta: Kanisius, 2011), 11.

${ }_{29}$ Michael Quin Patton, Qualitative Evaluations and Research Methods (Newbury Park: SAGE Pub, 1990), 390.

${ }^{30}$ Moh. Nazir, Metode Penelitian (Jakarta: Ghalia Indonesia, 1998), 23.

${ }^{31}$ Suharsimi Arikunto, Prosedur Penelitian (Jakarta: Rineka Cipta, 1993), 128.

${ }^{32}$ Koentjaraningrat, Metode-Metode Penelitian Masyarakat (Jakarta: PT. Gramedia Pustaka Utama, 1994), 144.
}

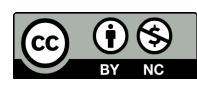

DOI: 10.19105/karsa.v29i1.4419 
method. ${ }^{33}$ So that the researcher was considered as an investigation triangulation. ${ }^{34}$ The data analysis method used is a deep analysis to process data from observations and interviews. In conducting data analysis, the researcher carried out several steps as expressed by Miles and Huberman, namely data reduction, exposing empirical material, drawing conclusions, or verifying. ${ }^{35}$

To describe the meanings and values of carok, the researcher used Michael Foucault's theory of power, discourse, and knowledge which are important and inseparable aspects of one another. The formation of carok legitimacy as conflict resolution cannot be separated from the discourse of power in social interaction in Madura. In social relations, power is a model that has become the mainstream in sustaining cultural destruction through conflict and violence. According to Foucault, power is a productive role in socio-cultural life and is developed through the knowledge media because it always establishes interrelated relationships in discourse construction. ${ }^{36}$ Foucault believes that power does not work through repressive actions but also by rules or norms. Power does not work negatively and repressively, but positively and productively. Foucault views that power is connected through social relations by producing forms of categorical attitude. ${ }^{37}$

In Madurese social relations, power gives birth to hegemonic practices that are present simultaneously. The practice of carok is the institutionalization of violence in the Madurese, which has a very strong relationship with cultural, social, economic, religious, and educational structural factors. When the carok becomes an instrument to achieve a higher social status, this practice of violence has simultaneously become

33 L. Moleong, Metodologi Penelitian Kualitatif (Bandung: Remaja Rosdakarya, 1993), 178.

${ }^{34}$ Norman K Denzin and Yvonne S. Lincoln (ed.), Handbook of Qualitative Research (London-New Delhi: SAGE Publications, 1994), 231.

${ }_{35}$ M.B. Miles and A.M. Huberman, Qualitative Data Analysis (California: SAGE PuB, 1984), 134.

${ }^{36}$ Michael Foucault, Archeology of Knowledge and Discourse of Language (New York: Pantheon Books, 1972), 123.

${ }^{37}$ M. Foucault, Power/ Knowledge: Selected Interview and Other Writing (New York: Pantheon, 1980), 27.

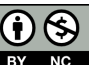

DOI: 10.19105/karsa.v29i1.4419 
the culture of the Madurese. A part of obtaining cultural justification, carok always gets social approval when acts of violence are aimed at maintaining family dignity.

In strengthening the theory that has been used, the researcher elaborates on Galtung's theory in analyzing carok which is considered part of cultural violence and legitimized by the power in social relations. According to Galtung, conflict is an act to gain respect and glory by become a winner and to show courage to restore dignity and self-respect through cultural violence. The carok case can be resolved through reconstruction, which includes rehabilitation with a traumatic approach to reduce the effects of trauma, rebuilding community relations with a relationship, restructuring with a peace-based community structure, and acculturation using a culture of peace approach. ${ }^{38}$

Forgiveness is understood as conflict resolution in suppressing the fast-growing carok in Madura. Forgiveness can be used as a set of motivations to change someone not to take revenge and reduce hatred towards the offending party and increase the urge to build reconciliation with the offending party. ${ }^{39}$ Forgiveness represents two important aspects. The interpersonal dimension that reflects a victim forgiving the perpetrator who has hurt her is not solely for the victim's self-interest, but precisely for the sake of helping the perpetrator; the perpetrator is not burdened with his past as an offender. ${ }^{40}$ The dimension of forgiveness could represent a stage of the cycle of violence. The hope for change in the partner can increase and achieve the probability of true reconciliation. ${ }^{41}$

\footnotetext{
${ }^{38}$ Johan Galtung, Handbook of Peace and Conflict Studies (New York: Routledge, 2007), 3

${ }^{39}$ Michael E. McCullough, et al., "Forgiveness, Forbearance and Time: The Temporal Unfolding of Transgression-Related Interpersonal Motivations," Journal of Personality and Social Psychology 73, no. 2 (2003): 321-336, https://doi.org/10.1037/ 0022-3514.84.3.540.

${ }^{40}$ E.L. Worthington, ed., Dimensions of Forgiveness: Psychological Research and Theological Perspectives (Radnor: Templeton Foundation Press, 1998), 79.

${ }^{41}$ Eleonora Crapoliccho, et al., "The Role of Relational Dependence, Forgiveness and Hope on The Intention to Return with an Abusive Partner," Journal of Social and Personal Relationships 38, no. 4 (2021): 1-20, https://doi.org/10.1177/0265407 5211011546.
}

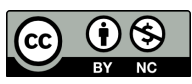

DOI: $10.19105 /$ karsa.v29i1.4419 


\section{Results \\ Carok, Blater, and Self-Dignity}

The case of carok that occurred in the village of Bujur Tengah, Batu Marmar, Pamekasan Madura in 2006 has attracted a lot of attention from the community from various regions. This area occurs collectively carok between two parties of the family who pour out all the anger and hatred for the sake of self-respect. In its development, this carok has become a national issue that is still lingering in the memory of the Madurese because it causes so many victims from two families. In the case of carok in Pamekasan, the problem for the land or village treasury triggered the occurrence of carok, which involved two figures, who were seen as representatives of strong people or blater.

In the context of local politics in Madura, village head elections are always contested by people who influence a blater. In the village, local politics shows that the blater has social roots, networks, and influence in the community. Blater is a village hero who is socially and culturally feared by all peoples because of his courage in facing every challenge. Likewise, with the figures of Mursyidin and Baidlowi, who were the actors in the case of carok in Bujur Tengah village several years ago. As a society figures, they both represent the world of spirituality which is part of the Madurese identity.

Many cases show that someone who was previously seen as not a blater, was later called a blater by other residents because he dared to do carok. If you win in the carok violence, it will further strengthen yourself as a blater. The community's mention of the figure of blater cannot be separated from the courage to do carok in dealing with conflicts and problems in the community. From here, carok is used as an arena of legitimacy to strengthen one's social status as a blater with a strong influence and an arrogant individual (angko). ${ }^{42}$

In the case of carok, the defense of the dignity between Mursyidin and Baidlowi can be interpreted as a battle between blater who have social status. For Baidlowi, controlling the village treasury land, although legally is an act that cannot be justified or violates the provisions, socially and culturally, it is one way for him to emphasize

\footnotetext{
42 Abdur Rozaki, Menabur Kharisma, 4-10.
}

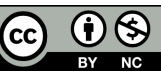

DOI: $10.19105 /$ karsa.v29i1.4419 
his predicate as blater. In Baidlowi's view, control of village treasury land has high economic value, so that it must be fought for even though it has to cost lives. When he is successful in controlling the village treasury land, his social status as a former village head or blater will increase because it involves issues of prestige, dignity, and self-respect.

The case of carok in Pamekasan was related to the struggle for the village land, which Baidlowi exchanged as a village head. For Baidlowi, land determines self-respect, and the value of the land will be greater for the life of the Madurese if their ancestors are buried in the land. From this, the land issue in Madura is an element that creates social conflict or carok when other people take away their rights. If carok occurs between family relatives, it can be ascertained that the main cause is the distribution of family inheritance. ${ }^{43}$ Other causes that can disturb the dignity of the Madurese, apart from issues of dignity for women, land, and ancestors, are also related to water issues and insult to religions.

Baidlowi's arrogant attitude made Mursyidin not accept it without any resistance efforts to take back the land that became the village treasury. For Mursyidin, the struggle to return village treasury lands is a must to safeguard important assets for village development. If there is a former village head who takes the village treasury land, it means that this can be interpreted as harassing the prestige and dignity of the village head. Mursyidin was even more disappointed and inflamed because the legal efforts he had made were found to have failed at the appeal level of the High Court in East Java. This condition made Mursyidin feel the need to re-question the status of the land to Baidlowi, who was considered to have committed the forgery or provided fictitious information to the society about the status of land that had been disputed in the High Court, East Java.

For Baidlowi, his victory at the appeal level (with an acquittal) is an achievement in itself that will further increase his prestige and social status as a blater. In the tradition of blater, winning a case in court is not only defined as a victory against an opponent in that legal action

${ }^{43}$ Andang Subaharianto, et al., Tantangan Industrialisasi Madura: Membentur kultur Menjunjung Leluhur (Malang: Bayumedia Publishing, 2004), 65-66.

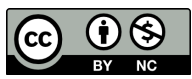

DOI: 10.19105/karsa.v29i1.4419 
but rather as a "victory" against judicial authority. ${ }^{44}$ Moreover, the appeal is accompanied by a branching method, namely an attempt to influence the judicial apparatus's decision by giving an amount of money according to the agreement. In the case of village treasury land disputes, it is possible for nabang (although it is difficult to find material evidence) so that the appeal decision finally acquires Baidlowi. On the one hand, this acquittal was a victory for Baidlowi; on the other hand, it hurt the Mursyidin's heart even more. The prestige and self-dignity of the village head had been trampled. It is easy to understand if carok finally exploded after the appeal decision was handed down. As fellow blater, Mursyidin and Baidlowi had many supporters. When the carok happened, loyal supporters joined in to defend their blatant patrons. Then there was a collective carok that claimed lives.

\section{The Dynamic and Potential of Forgiveness in the Case of Carok}

The existence of the forgiveness approach as conflict resolution and therapy in the case of carok in Madura originated from the initiative of the Kiais in pesantren to resolve the conflict between the two warring parties. The initiative, which came from the Kiais, was welcomed by the whole societies who desperately wanted to restore the village security conditions. This positive response from the community prompted the Kiais in pesantren to discuss the possibilities of meeting conflicting parties.

There are several pesantren in Pamekasan, which are directly involved in handling carok, namely pesantren Banyuanyar, pesantren Bata-Bata, pesantren Pakes, pesantren Bringin, and pesantren Panyepen. The kiais intervened in handling conflict resolution involving two groups between Mursyidin and Baidhowi. In the resolution of the carok, the figure of the Kiais became the main actor who could suppress the revenge action that held anger. Even though the case of carok in Pamekasan is part of the collective violence, the Kiais dare to embrace the parties involved in the conflict to carry out intense dialogue and deliberation to achieve genuine reconciliation, which is manifested in the spirit of brotherhood and kinship.

${ }^{44}$ A. Latief Wiyata, Mencari Madura (Jakarta: Bidik Publishing, 2013), 176.

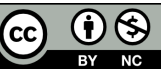

DOI: $10.19105 /$ karsa.v29i1.4419 
The existence of Kiais in the social and cultural reality of Madura becomes the center of solidarity and a source of role models in all aspects of life. The figure of the Kiais in resolving the carok conflict is very important, especially as a protector of the community to endure acts of violence in a sustainable manner. The existence of Kiais in conflict resolution occupies a strategic position because of the social construction formed in the life of the Madurese society. The use of awareness media through institutions represented by Kiais figures is more effective than formal educational institutions.

The Kiai's contribution to conflict resolution plays a role not only as a legal authority but as a mediator to carry out a dialogue with the parties involved in the case of carok, especially the families of victims. First, it functions as a facilitator who brings together two conflicting parties. In this model, several Kiai's meet to discuss the conflict to be mediated. Next, they invite the conflicting parties at different times to listen to the problems between the two parties. Second, as a mediator to resolve conflicts with careful considerations. Through the Kiai's role and contribution in resolving the case of carok in Pamekasan, both parties received advice and decisions without rejection or feelings of not accepting each other. After the case of carok, the people of Bujur Tengah Pamekasan slowly began to realize the importance of expressing their desires through good attitudes when faced with every conflict.

In this section, the researcher presents the dynamics and potential of forgiveness as an attitude of humility to eliminate hatred and anger due to the traumatic carok incident. Potential forgiveness means the possibility of reaching an agreement not to take revenge by the meaning and history of carok, which is full of cultural values. If the potential of forgiveness is colored in the dynamics of carok, then there should not be a second grudge after the achievement of self-esteem recovery.

The potential for forgiveness and reconciliation in the case of carok in Madura has emerged when a manly contest in defense of selfesteem. Before carrying out the carok action, it was usually prepared in a family session so that the enemy would not know about the plan. The existence of a family session before the carok was carried out

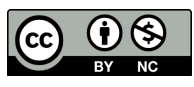

DOI: $10.19105 /$ karsa.v29i1.4419 
increasingly emphasized that carok was legitimized by socio-cultural institutions. The conflict that occurred initially was an individual conflict that developed or turned into a collective conflict. The researchers mean by a shifting paradigm in the case of carok in Pamekasan Madura.

The act of carok is a risk that must be faced by a person when his dignity is violated. Meanwhile, someone who insults self-respect means that he wants to take his own life when dealing with people who have hurt him. Usually, people who always get insulted or insinuated will eventually be motivated to do carok. This also aims to restore their self-respect, which an insult from the enemy has tainted. If the carok act is not carried out immediately, then some Madurese people are considered cowardly (ta' lake').

The potential for forgiveness and reconciliation in the case of carok appeared before the action was carried out, namely when someone received insults from others and tried to restore their trampled selfesteem by doing carok. As part of the culture in Madura, carok does not occur spontaneously or immediately without any background or motive to encourage it. The carok in Madura is the act that was not carried out individually, without careful preparation and ritual, but was carried out spontaneously and suddenly. One party, namely Mursyidin, was not in a ready condition because he did not carry a sickle weapon as a spare or a weapon used to perform carok. ${ }^{45}$ The occurrence of collective carok in Bujur Tengah Pamekasan indicates a carok shifting that has a sociocultural meaning in the life of the Madurese society.

\section{Carok and The Dimensions of Forgiveness}

After we know the dynamics and potential of forgiveness, the researcher attempted to describe the dimensions related to forgiveness that guarantees genuine reconciliation. Based on the forgiveness theory, its values have a significant influence on the family of the victim or perpetrator to end the conflict without the will to take revenge. The two dimensions referred to are the intrapsychic and interpersonal dimensions

\footnotetext{
${ }^{45}$ Interview with H. Makruf, one of the society figures in Bujur Tengah Village, on 19 February 2015.
}

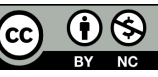

DOI: $10.19105 /$ karsa.v29i1.4419 
as a frame of mind in deciphering resolution patterns when the opportunity for forgiveness and reconciliation is wide open in conflict situations. ${ }^{46}$

Based on the dimensions of forgiveness as a theory in conflict resolution, the researcher effort to assess whether the carok conflict in Bujur Tengah Pamekasan has occurred forgiveness actions based on the dimensions of intrapsychic and interpersonal combinations or not? It can be seen from the argumentation of community leaders, Kiais, families of victims or perpetrators, and all society who know the processes of forgiveness and reconciliation. By looking at the two dimensions of forgiveness, the researcher correlates it with the dimensions of forgiveness found in the case of carok. The interpersonal dimension of forgiveness is reflects the victim of the family's willingness to forgive the offender who makes him hurt (sake 'ate) and hurt (loka). This action is not solely for the victim's self-interest but rather to help the perpetrator not be burdened as an offender. Meanwhile, the intrapsychic dimension is characterized by the willingness of the victim to get rid of anger or hatred towards the perpetrator and begin to understand events from the perpetrator's perspective.

In these two dimensions, forgiveness requires the sincerity to understand the inner turmoil and suffering buried deep in the heart. The understanding inner turmoil that reflects feelings of emotion and cognition is an essential dimension of achieving forgiveness. Meanwhile, understanding the social aspects of a person also plays an important role in suppressing hatred based on human values. Suppose the intrapsychic and the interpersonal dimension can interact with each other. In that case, it will produce several forgiveness combinations related to one another as a unit that encourages sincerity in giving and receiving apologies. The combination of the two dimensions of forgiveness produces hollow forgiveness (interpersonal act + no 'intrapsychic' state), total forgiveness (intrapsychic state + no interpersonal act), no forgiveness ('intrapsychic state' + interpersonal act), and silent forgiveness (no 'intrapsychic state' + no interpersonal act).

${ }^{46}$ Roy F. Baumeister, et al., "The Victim Role," 78.

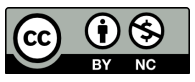

DOI: 10.19105/karsa.v29i1.4419 
This combination in forgiveness reflects a positive signal from the conflicting parties to forgive or not at all. By looking at this combination, several conclusions will be found about the steps taken by both parties, especially the case of a claw, whether to take the dimensions of a combination of hollow forgiveness, total forgiveness, no forgiveness, or silent forgiveness. If you choose one of the four combinations, what are the considerations and rational reasons that could encourage the families of carok victims to make this decision?

In this forgiveness combination, each of the families has expressed mutual forgiveness through expressions and verbally witnessed by several parties, namely the Kiais, the Regent of Pamekasan, and invited community figures in the meeting for the reconciliation forum. Besides, it is also accompanied by the intention of ending the conflict, releasing all anger and hatred, and promising not to take any action of revenge. The family said that the events that took place in July 2006 were over with the reconciliation initiated by the Kiais in Pamekasan Madura. ${ }^{47}$

Both parties have agreed to end the conflict, and there is no term of retaliation from the victims' families. If countermeasures still occur, whoever is involved and becomes the provocateur is ready to be shot on the spot as part of the agreed agreement. "I can confirm that the families of Mursyidin and Baidlowi have accepted all past incidents, especially since the involvement of the Kiais has given the public awareness of the importance of living to forgive each other without having to save and take hidden grudges." 48

Based on the forgiveness theory and developments in the case of carok, it can be said that it has reached the level of total forgiveness because each party agrees not to continue the land issue. In psychological theory, total forgiveness is integrating the interpersonal act and the intrapsychic state dimensions. Sincerity reflects someone in giving and receiving apologies based on humanity and love as a servant of God. It is consistent with Hannah Arendt's statement that love has the

\footnotetext{
${ }^{47}$ Interview with Hamdan, one of the Mursyidin families, on 27 March 2015.

${ }^{48}$ Interview with Badrus, on 7 March 2015
}

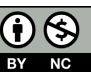

DOI: 10.19105/karsa.v29i1.4419 
power to forgive. Love bridges two parties, namely the victim and the perpetrator, to meet in one event. ${ }^{49}$

\section{Discussion}

\section{The Stages of Forgiveness in the Case of Carok}

In this study, it was found that forgiveness is accompanied by a desire not to take revenge and an effort to forget past events to build friendship and brotherhood in people's lives. However, the process of forgiveness cannot be done instantly because everyone needs time and mental readiness for making forgiveness. The more important action is goodwill or willingness to end the conflict so that acts of revenge do not occur between two opposing parties. The stages of forgiveness can be seen from the aspect of restoring security conditions through the involvement of community leaders and must be observed from the side of the victim's family or the perpetrator of an incident that brings the fire of hostility. The stages of creating mutual acceptance to end the conflict are accompanied by forgiveness after the situation and condition were considered safe.

\section{a. Restoration of Security Conditions}

To achieve the forgiveness stage in the case of carok, so need to the restoration of security conditions that involved all elements of society. This restoration of security conditions is based on Johan Galtung's approach, which provides three perspectives on conflict resolution. First, peacekeeping approach (security operations), which involving security forces and the military to reduce conflict and prevent conflict transmission to other groups. Second, peace-making is a negotiation model to achieve harmony. Third, peacebuilding is used as a strategy or effort to restore the destructive situation by building a communication bridge between the parties involved in the carok conflict.

The restoration of security conditions was initially focused on preventing further carok and the emergence of provocations that took

${ }^{49}$ Hannah Arendt, The Human Condition (London: The University of Chicago, 1959), 217.

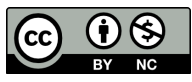

DOI: 10.19105/karsa.v29i1.4419 
advantage of situations and conditions to destroy society's life. For approximately three months, police officers from Pamekasan conducted patrols and were on guard around the location and residents' houses in anticipation of further carok. In the process of restoring the situation and security conditions of Bujur Tengah village, the role of community leaders is very important to reduce conflict. Kiai Ali Wafa is one of the community leaders who dared to calm down the village situation and conditions which were tense. As a community leader, Kiai Ali Wafa struggled to restore conditions by embracing all the parties. With a strong determination, Kiai Ali Wafa ventured to embrace each of them to speak heart to heart for the sake of restoring security and creating an attitude of mutual forgiveness for each another. ${ }^{50}$

\section{b. Restoring the Effects of Trauma with a Cultural Approach}

Kiai Ali Wafa's courage as a mediator for the two conflicting parties was based on the passion for restoring the security situation and conditions in people's lives. Many risks must be faced by Kiai Ali Wafa in restoring security conditions to achieve forgiveness and peace between the two parties. Kiai Ali Wafa often felt threats and terror various to embrace all parties involved in the case of carok.

Then, what is the strategy of Kiai Ali Wafa in embracing the two conflicting parties to end this conflict immediately and not to take revenge? One of them is by restoring the effects of trauma with a cultural approach to all society. Kiai Ali Wafa visited Mursyidin and Baidhowi's house to cool the hearts of the family, especially their sons and daughters. In the process of dialogue and deliberation, Kiai Ali Wafa advised them that the carok incident was a joint disaster between each family. ${ }^{51}$

It was initiated by Johan Galtung about how to restore the mental condition that erupted due to an event that gave bitter memories. Galtung offers a reconstruction path that includes rehabilitation with a traumatic approach to reduce the effects of trauma, rebuilding community relations with a relationship-building approach (macellep ate),

\footnotetext{
${ }^{50}$ Interview with Kiai Ali Wafa, on 25 March 2015

${ }^{51}$ Interview with Kiai Ali Wafa, on 28 March 2015.
}

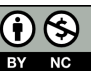

DOI: $10.19105 /$ karsa.v29i1.4419 
restructuring with a peace-based community structural approach, and acculturation which uses a culture of peace approach. ${ }^{52}$

\section{c. Silaturrahmi as a Process of Preventing Conflict}

Recovery of the victim's family's condition requires a long process because it is still experiencing trauma and pressure. The restoration of the mental condition begins with intense friendship who is very influential in rebuilding the relationship. This can be done by restrengthening the bonds of friendship by providing opportunities for all the family to express feelings of emotional wounds that had flared up. Based on Kiai Ahmad's view, when the researcher conducted a direct interview at his house, he said that if the problem could still be resolved by a kinship way, then this approach was applied. The familial method must be an important foundation for all people to resolve the carok conflicts. $^{53}$

In the case of carok, the forgiveness process was well accepted because each victim's family received offers and good intentions from the Kiais in Pamekasan Madura. Many Kiais conducted friendships with the families of carok victims, such as KH. Muhammad Rafii Baidhawi (pesantren Banyu Anyar), KH. Muhammad Syamsul Arifin (pesantren Banyu Anyar), KH. Hasan Abdul Hamid, and KH. Thoriq Abdul Hamid (pesantren Bata Bata), K. Mudassir (pesantren Panyepen), K. Asnawi (pesantren Pakes), and K. Ali (pesantren Bringin), and other pesantren in Pamekasan Madura.

The Kiais and community leaders used the path of friendship as an important step in restraining the emotions and anger of their families over what happened to them. In the case of carok, the means of friendship are used to establish communication and dialogue between families with feelings of sympathy and empathy. With the role of the Kiais, the families of carok victims can realize that the events as a valuable lesson in their socio-religious activities. The path of friendship

\footnotetext{
52 Johan Galtung, Peace by Peaceful Means: Peace and Conflict, Development and Civilization (Londong: SAGE Publication, 1996), 78.

${ }^{53}$ Interview with Kiai Ahmad, on 22 February 2015
} 
can be achieved because the Madurese have a sense of togetherness as a part of big families.

\section{d. Tabayyun as a Conflict Management Process}

The resolution of the carok conflict also requires more attention not only from the government as a power holder but also from Kiais in efforts to bring genuine reconciliation between the two parties involved in carok. From the collaboration between the government, the police apparatus, and the Kiais in pesantren, so there are many opportunities to implement the importance of tabayyun as a process of regulating and managing the carok conflict.

The tabayyun process is an important step taken by community leaders and Kiais to clarify the real problem that occurs between the two conflicting parties by involving representatives of their respective families. Tabayyun comes from an Arabic word that means an in-depth explanation. The elements contained in the tabayyun process include presenting parties in conflict, mediators who can be accepted, and each family representative.

After the Kiais provided conflict resolution, the families of Mursyidin and Baidlowi were welcome to respond whether the offered solutions could be accepted or rejected. The answer to the tabayyun process can be seen from the forgiveness mechanism found in the case of carok, to be precise, when family representatives from both parties met in pesantren where the forgiveness and reconciliation processes were achieved. From here, the Kiais involved in carok conflict resolution reveal the foundation that strengthens the importance of the forgiveness process for both parties for the sake of mutual understanding.

\section{The Power of Forgiveness Therapy: Models of Conflict Resolution in the Case of Carok}

Conflict resolution refers to the solution of real conflicts (manifest) by changing the parties' attitudes, views, and ultimate goals. Models of conflict resolution in Madura also used local wisdom as one

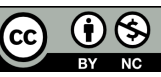

DOI: 10.19105/karsa.v29i1.4419 
of the alternative approaches. ${ }^{54}$ The conflict resolution mechanism aims to provide solutions that are accepted by all societies. This will make them have an interest in providing conflict resolution that is acceptable to all parties so that they can reduce the potential for further violence. ${ }^{55}$ There are several models of forgiveness in resolving the carok conflict in Madura.

\section{a. Problem Solving Dialogue}

The achievement of forgiveness in the case of carok is largely determined by problem-solving dialogue as an aspect of emphasis as well as insulation. In problem-solving dialogue, this process occurs to resolve issues that concern the interests of the two conflicting parties. ${ }^{56}$ The presence of this problem-solving of dialogue in the case of carok cannot be separated from the goodwill of each family to make big decisions, namely no longer blaming the land for the competition that was previously contested. From this goodwill, the family strives to accept everything that happens and is ready to applicate of forgiveness process and reconciliation through the advice of the Kiais.

In the problem-solving of dialogue, Kiai Ali negotiated to ensure that the forgiveness process was achieved as reconciliation. Deliberations are held freely to reveal all views regarding the right solution. Even though there are many frictions over what happened, when it becomes a decision, all parties must obey it. As a process of achieving forgiveness among the families of carok victims, Kyai Ali from pesantren Bringin was very intense in making visits to the families of the carok victims to provide advice that could be accepted by all the parties. For Kiai Ali, the case of carok must be resolved immediately because it could cause a fire of enmity in the husks.

${ }^{54}$ Cahyono, "The Model of Penal Mediation as A Countermeasures of Violence Conflict (Carok) in Madurese Society Based on The Local Wisdom," Jurnal Hukum dan Peradilan 8, no. 2 (2019): 289, https://doi.org/10.25216/JHP.8.2.2019.275-296.

${ }_{55}$ Ashutosh Varshney, ed., Collective Violence in Indonesia (London: Lynne Rienner Publisher, Inc, 2010), 53.

56 David Norris, Forgiving from the Heart (New York: Harper Collins Publisher, 1984), 45.

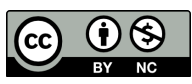

DOI: 10.19105/karsa.v29i1.4419 
So, the first thing that was done to resolve the case of carok based on religious and cultural values was to provide an opportunity for the recognition of the culture of deliberation in the life of the Madurese society. This effort can be successful if the dominance of state law in all its aspects is minimized. Not all carok conflicts that occur in Madura can be resolved through procedures and processes provided by state law, but by making the cultural values of the Madurese society, such as deliberation, a "tool" to guide them.

\section{b. Facilitating the "Reconciliation Forum"}

Then what is the good mechanism or model for forgiveness to reach a peace agreement between the two parties that have been involved in the case of carok In Madura? To restore the security situation, the kiais from the pesantren were actively involved in reconciling the two parties involved in carok. The Kiais came from pesantren Bata-Bata, pesantren Banyuanyar, pesantren Pakes, and pesantren Bringin. Through the Kiai's central role, efforts to find a solution to the conflict that occurred to be intensified. At its peak, each of the parties involved in the case of carok, namely the family as delegates, was invited directly to attend a muhasabah process which would later be followed up by the existence of recess.

In the pesantren, both parties were invited and gathered to discuss the problems that had occurred in the hope that there was a common ground. Through the muhasabah process, the forgiveness approach was wide open between the two parties. Muhasabah is carried out as a form of reflection on the events that occurred with a shared spirit to improve relations or kinship between the two parties and all the people in Madura. Each family party is given time to say the best hope and will for a resolution of the protracted conflict due to the collective carok.

When each family representative was given time to express their hopes and desires, the Kiais and elements who attended the reconciliation forum accommodated all the best aspirations and choices of each of them. After that, what they wanted from this issue was discussed to find the best way for a peace agreement for the common interests of both parties and the other people. The hopes and desires of

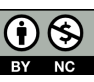

DOI: $10.19105 /$ karsa.v29i1.4419 
family representatives from the two parties were not much different because basically, they wanted to improve their relationship and open the door as wide as possible for forgiveness and reconciliation, which were the goals of their presence at the pesantren Pakes Pamekasan Madura.

After going through muhasabah way and deep reflection on the problems, the leader of the reconciliation forum represented by Kiai Ali advised on the importance of building a spirit of brotherhood in their families. Based on this kiai's advice, both parties began to realize that what happened was a disaster that must be ended and forgotten for the sake of the common future. With the spiritual advice of the kiais in pesantren Pakes, both parties agreed to end the conflict and there was no word of revenge in the future. Through a familial deliberation, an agreement was reached not to question the court issue again, and the land was handed back as the treasury of the village. Another agreement is if there is still a follow-up carok involving both parties, then they are welcome to be shot at the location of the incident.

\section{c. Religious Ritual to Achieve Genuine Reconciliation}

When the forgiveness approach and a peace agreement are established in the spirit of kinship in pesantren, the security atmosphere in Bujur Tengah village became better and returns to normal life. The relationship between the two families also has a positive impact on the establishment of a sense of security and harmony in the life of society. The reconciliation forum was initiated by kiais, the life of the people of Bujur Tengah, which was tense, turned into a good atmosphere.

Religious ritual is held in each mosque in Bujur Tengah village, which is attended by the community leaders and families involved in the case of carok. The purpose of carrying out this monthly recitation activity (religious ritual) is to continue to remind the public always to maintain the spirit of kinship and brotherhood and avoid violence. Based on this activity, every people are expected to have an awareness of religion and not be easily provoked by emotions. Besides, the community is also expected to always maintain harmony for the sake of creating an atmosphere of life that is full of coolness and peace. It is necessary to have a local mechanism that can prevent or reduce the

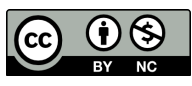

DOI: $10.19105 /$ karsa.v29i1.4419 
occurrence of violence in Madura, for example, by holding a custom of peace accompanied by mutual forgiveness. However, until now, no social institution has acted as a deterrent to carok.

Kiai Ali Wafa, who serves as the acting head of the village of Bujur Tengah, said that the reconciliation that is held every month is a reconciliation practice for community harmony, which was split due to the collective carok that occurred in July 2006. This reconciliation practice is a follow-up to the forums that have been carried out at the pesantren Pakes and the pesantren Banyuanyar Pamekasan. It is said that the reconciliation practice is because the families of the carok victims and the community as a whole mingle together in one very cool and quiet place. The atmosphere of kinship and brotherhood in each of these recitation events looks harmonious and hydrated to accompany the Prophet's prayers which are often implemented by Kiais to cool the inner turmoil so that he always remembers Allah and His Messenger.

\section{Conclusion}

The forgiveness model in the case of carok was chosen as a conflict resolution capable of controlling anger and retaliation to achieve true reconciliation. The forgiveness mechanism has extraordinary power to rebuild the relationship or restore the trauma's effects from the victim's family. The presence of a forgiveness mechanism in the case of carok cannot be separated from the role of Kiai in several pesantren to resolve disputes between two parties.

The Kiais undertake several stages and mechanisms to accelerate the achievement of reconciliation. First, restoration of security conditions provides three perspectives on conflict resolution, namely peacekeeping and peacebuilding. Second, embracing the families of the carok victims to refrain from taking revenge. Third, streng-then silaturrahmi as a process of countering conflict prevention. Fourth, the tabayyun process aims to clarify the problems of the two warring parties. Fifth, accelerate problem-solving dialogue as an aspect of emphasis that reflects the dialogue process. Sixth, presenting family representatives of both parties at the pesantren which is intended to accelerate the process of achieving conflict resolution through forgiveness and reconciliation. Seventh, holding a monthly

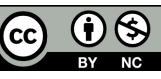

DOI: $10.19105 /$ karsa.v29i1.4419 
reconciliation recitation study for the harmony of the community, which had been divided by the collective carok.

The possibility of achieving forgiveness and reconciliation actions will be more effective if there is an institution that regulates it. In the life of the Madurese people, there are influential social elements, namely the figures of buppa', babu', guru, rato, need to be made effective to provide awareness to the community about the importance of obedience in carrying out the advice or messages that have been given by these four figures. Thus, the roles of these four figures need to be optimized, including the institutions represented by the kiai as mediators in the life of the Madurese community.

Local symbols become essential as a unifying tool that can build communication to achieve true reconciliation. New symbolic behavior expressions that reflect harmony values in the spirit of kinship are needed to create reconciliation. Symbolic expressions can have a positive influence on the creation of a reconciliation. There are cultural values related to a harmonious life reflected in the expression: rampak naong bringen korong.

\section{Bibliography}

Abdurrahman. Masalah Carok di Madura. Buku Madura III. Surabaya: Sinar Terang, 1987.

Arendt, Hannah. The Human Condition. London: The University of Chicago, 1959.

Arikunto, Suharsimi. Prosedur Penelitian. Jakarta: Rineka Cipta, 1993. Auerbach, Yehudit. "Forgiveness and Reconciliation: The Religious Dimension." Terrorism and Political Violence 17, no. 1 (2005): 469-485. https://doi: 10.1080/09546550590929174.

Budiyanti, Syamsu, Hotman M. Siahaan, and Kris Nugroho. "Social Communication Relation of Madurese People in Max Weber Rationality Perspective." Jurnal Studi Komunikasi 4, no. 2 (2020): 389-409. https://doi.org/10.25139/jsk.v4i2.2447.

Cahyono "The Model of Penal Mediation As A Countermeasures Of Violence Conflict (Carok) in Madurese Society Based On The Local Wisdom." Jurnal Hukum dan Peradilan 8, no. 2 (2019): 275-296. https://doi.org/10.25216/JHP.8.2.2019.275-296.

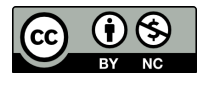

DOI: 10.19105/karsa.v29i1.4419 
Crapoliccho, Eleonora, Camalio Regalia, Gian Antonio Di Bernardo, and Vincenza Cinquegrana. "The Role of Rational Dependence, Forgiveness and Hope on The Intention to Return with an Abusive Partner." Journal of Social and Personal Relationships 38, no. 4 (2021): 1-20. https://doi.org/10.1177\%2F0265407521 1011546.

Dharmawan, A., G.G. Aji, and Mutiah. "Madurese Cultural Communication Approach." Journal of Physics: Conference Series 953, no. 1 (2018): 1-6. http://doi.org/10.1088/1742-6596/ 953/1/012195.

Denzin, Norman K., and Yvona S. Lincoln. Handbook of Qualitative Research. London-New Delhi: SAGE Publications, 1994.

Fahrenholz, Geiko Muller. The Art of Forgiveness: Theological Reflections on Healing and Reconciliation. Jeneva: WWC Publication, 1997.

Fitriana, M. Abu. The Spirit of Forgiveness: Hidup Indah dengan Memaafkan. Solo: Tinta Media, 2013.

Foucault, Michael. Archeology of knowledge and Discourse of Language. New York: Pantheon Books, 1972.

Foucault, Michael. Power of Knowledge: Selected Interviews and Other Writing. New York: Pantheon, 1980.

Galtung, Johan. Handbook of Peace and Conflict Studies. New York: Routledge, 2007.

Galtung, Johan. Peace by Peaceful Means: Peace and Conflict, Development and Civilization. London: SAGE Publication, 1996.

Gani, Asep Haerul. Forgiveness Therapy: Maafkanlah, Niscaya Dadamu Lapang. Yogyakarta: Kanisius, 2011.

Gopin, Marc. "Forgiveness as an Element of Conflict Resolution in Religious Cultures: Walking the Tightrope of Reconciliation and Justice." In Reconciliation, Justice and Co-existence, edited by Muhammad Abu Nimer, 1-39. Lanham: Lexington Books, 2001.

Haris. "Religiosity of Violence Through Pesantren: A Method to Prevent Carok in Madura Tribe of Indonesia." Journal of Law, Policy, and Globalization 2, no. 57 (2017): 55-63. https://www. iiste.org/Journals/index.php/JLPG/article/view/35172.

Jonge, Huub De. "Stereotypes of Madures." In Across Madura Strait: The Dynamic of an Insular Society, edited by Huub De Jonge, Elly

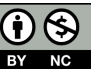

DOI: 10.19105/karsa.v29i1.4419 
Touwen-Bouwsma, and Kees Van Dijk, 7-24. Leiden: KITLV Press, 1995.

Julijanti, Dinara Maya, Yayan Sakti Suryandaru, and Myrtati Dyah Artaria. "Remo Celebration in Blater Community: Traditional Ritual Communication in Madura." Jurnal Studi Komunikasi 4, no. 2 (2020): 296-310. https://doi.org/10.25139/jsk.v4i2.2445.

Koentjaraningrat. Metode-Metode Penelitian Masyarakat. Jakarta: PT. Gramedia Pustaka Utama, 1994.

Miles, Matthew B., and A. Michael Huberman. Qualitative Data Analysis. California: SAGE Publications, 1984.

McCullough. "Forgiveness, Forbearance and Time: The Temporal Unfolding of Transgression-Related Interpersonal Motivations." Journal of Personality and Social Psychology 72, no. 2 (1997): 231-336. https://doi.org/10.1037/0022-3514.84.3.540.

Moleong, Lexy. Metode Penelitian Kualitatif. Jakarta: Remaja Rosdakarya, 1994.

Nazir, Moh. Metode Penelitian. Jakarta: Ghalia Indonesia, 1998.

Norris, David. Forgiving from the Heart. New York: Harper Collins Publisher, 1984.

Patton, Michael Quin. Qualitative Evaluations and Research Methods. Newbury Park: SAGE Pub, 1990.

Pickering, Peg. How To Manage Conflict: Kiat Menangani Konflik. Translated by Masri Maris. Jakarta: Erlangga, 2001.

Baumeister, Roy F., Julie Juola Exline, and Kristin L. Sommer. "The Victim Role, Grudge Theory, and Two Dimensions of Forgiveness." In Dimensions of Forgiveness: Psychological Research and Theological Speculations, edited by Everett L. Worthington, 79-104. Philadelphia: The Templeton Foundation Press, 1998.

Rahmi, Purwati Ayu, Cahyaningrum Dinis, Putri Kholifatul Wanda, and Listiyawaty Yuyun. "Meaning of Carok For Maduranese (Indonesian Tribe): A Case Study in Sampang." RJOAS 2, no. 74 (2018): 11-16. https://doi.org/10.18551/rjoas.2018-02.02.

Rahmi, Purwati Ayu. "Maduranese Meaning About Carok Case Study in Sampang Regency, Madura Island." The $5^{\text {th }}$ Asian Academic

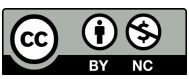

DOI: $10.19105 /$ karsa.v29i1.4419 
Society International Conference. 2017. http://aasic.org/proc/ aasic/article/view/306.

Rifai, Mien Ahmad. Manusia Madura: Perilaku, Etos Kerja, Penampilan, dan Pandangan Hidupnya. Yogyakarta: Pilar Media, 2007.

Rochmadi, Nur Wahyu. "Virtues of the Madura Society." Advances in Social Science, Education, and Humanities Research, Proceedings of the 1st International Conference on Character Education. 2020. https://doi.org/10.2991/assehr.k. 210204.025.

Rohman, Syaiful, Margaretha Hanita, and Ahmad Luthfi. "The Influence of Carok Culture on Reproductive Violence for the Younger." Conference: Proceedings of the 2nd International Conference on Strategic and Global Studies. 2018. https://eudl.eu/ pdf/10.4108/eai.24-10-2018.2289677.

Rozaki, Abdur. Menabur Kharisma, Menuai Kuasa: Kiprah Kiai dan Blater Sebagai Rezim Kembar di Madura. Yogyakarta: Pustaka Marwah, 2004.

Smedes, Lewis B. Forgive and Forget: Healing The Hurts We Don't Deserve. San Fransisco: Harpersan, 1984.

Smith, Glen. "Carok Violence in Madura, From Historical Conditions to Contemporary Manifestations." Folk: Journal of the Danish Ethnographic Society, no. 39 (1997): 57-75. https://koha.ups22 59.vjf.cnrs.fr/cgi-bin/koha/opac-detail.pl?biblionumber=12297.

Subaharianto, Andang. Tantangan Industrialisasi Madura: Membentur Kultur Menjunjung Leluhur. Malang: Bayumedia Publishing, 2004.

Touwen-Bouwsma, Elly. "Kekerasan di Madura." In Agama, Kebudayaan, dan Ekonomi: Studi-Studi Interdisipliner tentang Masyarakat Madura, edited by Huub De Jonge. Jakarta: Rajawali Press, 1989.

Tridatno, Yoachim Agus, J.B. Banawiratma, and Wening Udasmoro. "Forgiveness: Its Power and Complexities." Orientasi Baru: Jurnal Filsafat dan Teologi 20, no. 2 (2011): 177-192. https://ejournal.usd.ac.id/index.php/job/article/view/1268.

Tutu, Desmond. No Future Without Forgiveness. London: Rider, 1999.

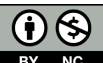

DOI: 10.19105/karsa.v29i1.4419 
Varshney, Ashutosh. Collective Violence in Indonesia. London: Lynne Rienner Publisher, 2010.

Wahiduddin, Maulana. The Ideology of Peace. New Delhi: Good work Books, 2010.

Wiyata, A. Latief. Carok: Konflik Kekerasan dan Harga Diri Orang Madura. Yogyakarta: LKiS, 2002.

Wiyata, A. Latief. Mencari Madura. Jakarta: Bidik Publishing, 2013. Worthington, Everett. L., ed. Dimensions of Forgiveness: Psychological Research and Theological Perspectives. Radnor: Templeton Foundation Press, 1998.

Yasin, Moh. Fatah, and Firmier Liadi. Representasi Nilai Budaya Madura \& Dayak dalam Sastra. Yogyakarta: IRCiSoD, 2007. 